POLITYKA ENERGETYCZNA - ENERGY POLICY JOURNAL

$2019 \star$ Volume $22 \downarrow$ Issue $4 \uparrow 21-36$

DOI: $10.33223 / \mathrm{epj} / 113369$

\title{
Evaluation of the economic efficiency of hydrogen production by lignite gasification
}

ABSTRACT: Hydrogen as a raw material finds its main use and application on the Polish market in the chemical industry. Its potential applications for the production of energy in fuel cell systems or as a fuel for automobiles are widely analyzed and commented upon ever more frequently.

At present, hydrogen is produced worldwide mainly from natural gas, using the SMR technology or via the electrolysis of water. Countries with high levels of coal resources are exceptional in that respect, as there the production of hydrogen is increasingly based on gasification processes. China is such an example. There some $68 \%$ of hydrogen is generated from coal.

The paper discusses the economic efficiency of hydrogen production technologies employing lignite gasification, comparing it with steam reforming of natural gas technology (SMR). In present Polish conditions, this technology seems to be the most probable alternative for natural gas substitution.

For the purpose of evaluating the economic efficiency, a model has been developed, in which a sensitivity analysis has been carried out. An example of the technological process of energy-chemical

$\triangle$ Corresponding Author: Michał Kopacz; e-mail: kopacz@min-pan.krakow.pl

1 Mineral and Energy Economy Research Institute of the Polish Academy of Sciences, Kraków, Poland; ORCID iD: 0000-0001-6475-8206; e-mail: kopacz@min-pan.krakow.pl

2 Faculty of Management, AGH University of Science and Technology, Kraków, Poland; ORCID iD: 0000-00031596-9749; e-mail: rkaplan@zarz.agh.edu.pl

3 Faculty of Management, AGH University of Science and Technology, Kraków, Poland; e-mail: kkwasnie@zarz. agh.edu.p

2019. The Author(s). This is an open-access article distributed under the terms of the Creative Commons Attribution-ShareAlike International License (CC BY-SA 4.0, http://creativecommons.org/licenses/by-sa/4.0/), which permits use, distribution, and reproduction in any medium, provided that the Article is properly cited. 
processing of lignite has been presented, based on the gasification process rooted in disperse systems, characteristics of the fuel has been discussed, as well as carbon dioxide emission issues. Subsequently, the assumed methodology of economic assessment has been described in detail, together with its key assumptions. Successively, based on the method of discounted cash flows, the unit of hydrogen generation has been determined, which was followed by a detailed sensitivity analysis, taking the main risk factors connected with lignite/coal and natural gas price relations, as well as the price of carbon credits (allowances for emission of $\mathrm{CO}_{2}$ ) into account.

KEYWORDS: hydrogen production, coal gasification, $\mathrm{SMR}$, economic evaluation, $\mathrm{CO}_{2}$ allowances

\section{Introduction}

Technological progress on the one hand, and the change of macroeconomic conditions on the other hand are the main factors which stimulate the development of chemical technologies. Chemical companies strive to improve their technical and economic results via the introduction of ever more recent technologies, as well as the modernization of the existing ones. New technological solutions are expected to provide the highly efficient processing of energy in products, to minimize the negative environmental impact, or to provide high operational flexibility, also regarding the use of various types of initial raw material.

The share of coal/lignite, crude oil, and natural gas in contemporary chemical production worldwide is subject to dynamic changes in time, as a result of the overlaying of several concurrent processes (BP 2019). On the one hand, we face the continuous development of technologies and improved production efficiency connected with that, on the other hand changes are enforced by the availability of resources and the level of their prices. Recently, another factor, the political one, has been playing an increasingly important role, as it is connected with energy security and environmental protection standards (Kaliski and Szurlej 2009). As a result, the share of basic raw materials, such as oil, gas, and coal/lignite in the production of base chemical intermediate products is different in various parts of the world. In China, a country that is abundant with coal resources, the shortage of oil and natural gas is compensated by launching a widespread coal gasification program (Lockhart and Robertson 2013).

The increasing demand for gas is strongly influenced by European Union regulations in the Framework of the so-called winter package, supporting the technologies with emission levels below $550 \mathrm{~g} \mathrm{CO}_{2} / \mathrm{kWh}$. Thus, gas technologies are promoted, which comply with those limitations. Renewable energy sources also are used. The consequences of the winter package for Poland will imply the gradual replacement of coal/lignite with other energy carriers (EP of the EU 2019).

The gasification of coal is perceived as a technology which is attractive for the chemical sector, not only due to the possibilities of diversifying the sources of raw materials, but also because it limits the influence of oil and gas suppliers. On the other hand, some 40 million Mg of hydro- 
gen are produced worldwide every year (Chmielniak 2014). For economic reasons, it is produced on a commercial scale mainly from natural gas, using steam reforming technology (SMR).

On a commercial scale, in countries which have coal resources and can develop them at low cost, hydrogen is produced in the processes of gasification and hydrolysis. At present, China represents around a third of total hydrogen production and about $85 \%$ of coal-based hydrogen production globally, but most of the hydrogen is currently used in chemical production and petrochemical refining activities as feedstock (Yang 2019). In the EU nomenclature, such hydrogen is considered 'brown' ("brown hydrogen"), as opposed to the so-called "blue hydrogen" produced from gas.

At the present stage of development of the chemical industry in Poland, natural gas is used in a vast majority of cases for the production of hydrogen and ammonia, where ammonia is the main intermediate product in the technological process of producing nitrogen artificial fertilizers (Surygała 2008). Hydrogen is also utilized in other processes in chemical plants, e.g. for hydrogenation of benzene when producing caprolactam, hydrogen peroxide, or other substances. The total demand for hydrogen is assessed at the level of about 150 million $\mathrm{Nm}^{3} / \mathrm{yr}$, which is reflected in the natural gas yielding about 60 million $\mathrm{Nm}^{3}$ a year. As a result, in the segment of hydrogen and ammonia production, the demand for natural gas may be estimated at the level of 2.1 billion $\mathrm{Nm}^{3}$ a year, with a perspective of slight increase every year.

Apart from the application of hydrogen as a raw material in chemical plants, its prospective applications for the production of energy in fuel cell systems or a fuel for automobiles have been widely analyzed and commented upon. Although the potential of applications in this area seems vast indeed, apart from the issues related to process and economic efficiency related to hydrogen generation and use, the issues connected with its storage and transport, which makes the perspective of such applications a significantly more distant one, are a vital element (Chmielniak 2014; Luque and Speight 2015).

\section{Technological arrangements analyzed}

Two variants of technologies for generation of hydrogen are analyzed in the paper, namely:

$\checkmark$ Gasification of lignite in the Shell reactor - in the analyzed technology, lignite is dried of its inherent moisture, to the level of $12 \%$ humidity. The heat required for the drying process is obtained by combusting tail gas remaining from the hydrogen separation process. Dried lignite is fed to the Shell reactor, in which the gasification process takes place. The gasification agent is oxygen and a small amount of steam. The synthesis gas, cooled down to the temperature of $230^{\circ} \mathrm{C}$ is subsequently purified and fed to the Gas Shift Reactor, in which carbon monoxide, in a reaction with steam generated in process of gas cooling, is converted to $\mathrm{H}_{2}$ and $\mathrm{CO}_{2}$. Hydrogen is generated in that reaction. Hydrogen is liberated from purified and enriched synthesis gas, with the efficiency of about $80.0 \%$, it is then subjected to purification 
process to obtain the purity level of $99.9 \%$. Effective installation work time over the year is 7,884 hours (Chmielniak et al. 2013).

- Steam reforming of natural gas (SMR) - natural gas purified from sulfur compounds, together with steam, is sent to the reforming unit, where the reforming process takes place, with the following reactions taking place:

$\mathrm{CH}_{4}+\mathrm{H}_{2} \mathrm{O}=\mathrm{CO}+3 \mathrm{H}_{2}$

$\mathrm{H}_{2} \mathrm{O}+\mathrm{CO}=\mathrm{CO}_{2}+\mathrm{H}_{2}$

Steam is the oxidizing agent in that process. Those reactions are strongly endothermic, that is why holding up their course is provided by means of heating with flue gases generated in the process of burning tail gas (after the process of hydrogen separation), also of natural gas if need be. Hydrogen is separated from purified synthesis gas, with the efficiency of $80.0 \%$. That hydrogen is subject to a purification process, to the required purity level equal to $99.9 \%$. The effective installation work time over the year is assessed at 7,884 hours (Kwaśniewski et al. 2015; McHugh et al. 2005).

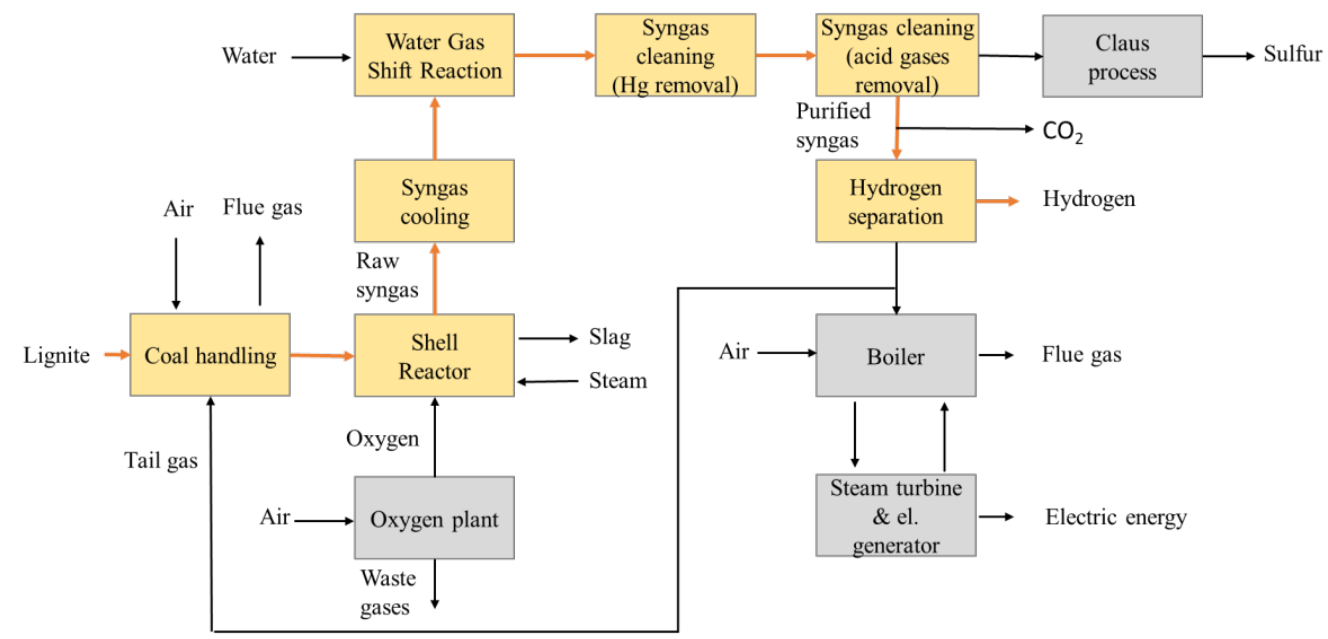

Fig. 1. Block diagram of hydrogen production through the gasification process with the use of Shell reactor (Kwaśniewski et al. 2015)

Rys. 1. Schemat blokowy technologii produkcji wodoru przez zgazowanie węgla w technologii Shell

The scale of analyzed technologies corresponds to the consumption of chemical energy in the amount of some $1935 \mathrm{GJ} / \mathrm{h}$. The balance calculations have been performed for the same availability of systems, at the level of $90.0 \%$. It has also been assumed that in case of coal gasification, a portion of chemical energy will be meant for own consumption, thus the yearly net production capacity is at the amount of 74.0 thousand $\mathrm{Mg} \mathrm{H}_{2}$ for brown coal/lignite consumption amounting to 15920 thousand $\mathrm{Mg}$.

In the case of the technology of the steam reforming of natural gas (SMR; steam methane reforming), the technology does not assume the generation of electricity for internal purposes, 


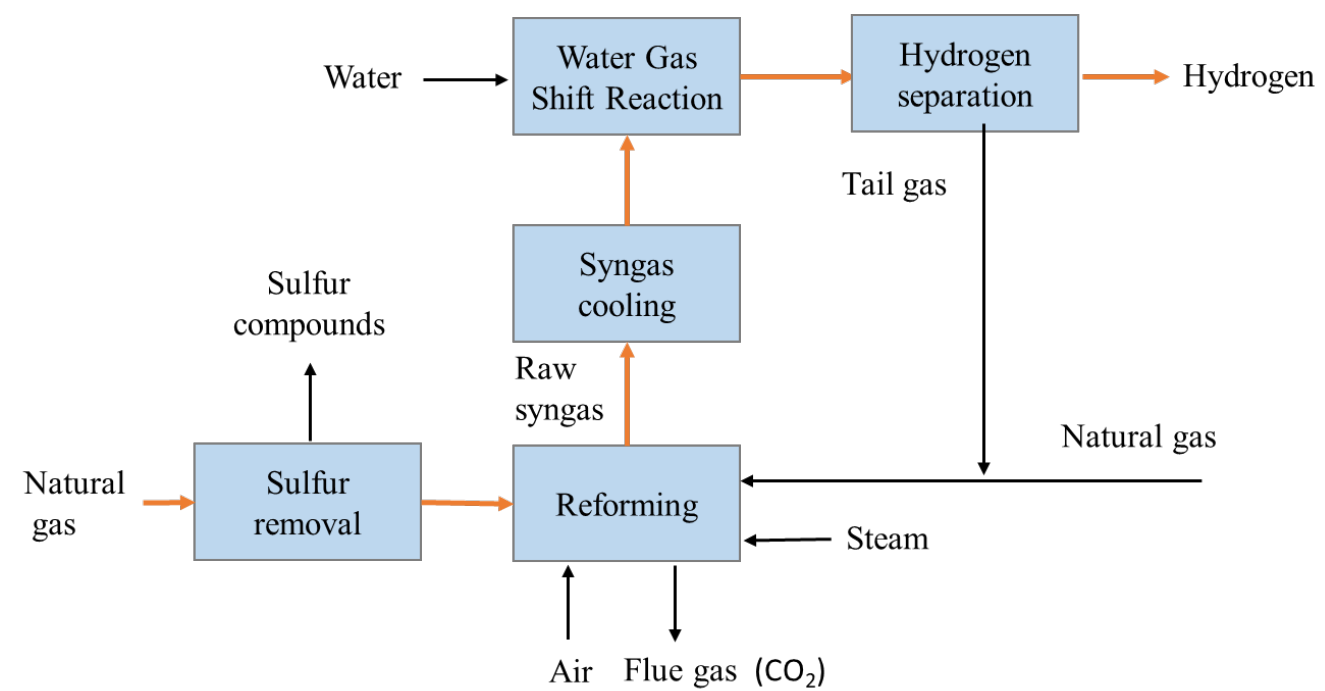

Fig. 2. Block diagram of the hydrogen production technology in the SMR process (steam reforming of natural gas) (Kwaśniewski et al. 2015)

Rys. 2. Schemat blokowy technologii produkcji wodoru na drodze reformingu parowego gazu ziemnego

only its purchase, thus the scale of hydrogen generation is higher in such a case, and amounts to 104 thousand $\mathrm{Mg}$ per year, with gas consumption amounting to 472.1 million $\mathrm{m}^{3}$.

Tables 1 and 2 contain characteristics of both fuels.

TABLE 1. Characteristics of lignite elemental composition and energy specification

TABELA 1. Analiza składu pierwiastkowego i wartości energetycznej węgla brunatnego

\begin{tabular}{|l|c|c|}
\hline \multicolumn{1}{|c|}{ Physical analysis } & Unit & Lignite \\
\hline Moisture & {$[\%]$} & 48.8 \\
\hline Carbon & {$[\%]$} & 32.0 \\
\hline Hydrogen & {$[\%]$} & 2.48 \\
\hline Nitrogen & {$[\%]$} & 0.39 \\
\hline Chlorine & {$[\%]$} & 0.01 \\
\hline Sulfur & {$[\%]$} & 0.03 \\
\hline Ash & {$[\%]$} & 5.49 \\
\hline Oxygen & {$[\%]$} & 10.8 \\
\hline Total & {$[\%]$} & 100 \\
\hline Higher heating value (HHV) & {$[\mathrm{GJ} / \mathrm{Mg}]$} & 12.39 \\
\hline Lower heating value (LHV) & {$[\mathrm{GJ} / \mathrm{Mg}]$} & 10.65 \\
\hline
\end{tabular}

Source: own study based on Kwaśniewski et al. 2015. 
TABLE 2. Natural gas specification

TABELA 2. Charakterystyka składu gazu ziemnego

\begin{tabular}{|c|c|c|c|c|c|}
\hline $\begin{array}{c}\text { Methane } \\
\text { content } \\
{[\%]}\end{array}$ & $\begin{array}{c}\text { Ethane } \\
\text { content } \\
{[\%]}\end{array}$ & $\begin{array}{c}\mathrm{CO}_{2} \text { content } \\
{[\%]}\end{array}$ & $\begin{array}{c}\text { Higher heating value } \\
{\left[\mathrm{kWh} / \mathrm{m}^{3}\right]}\end{array}$ & $\begin{array}{c}\text { Lower heating value } \\
{\left[\mathrm{kWh} / \mathrm{m}^{3}\right]}\end{array}$ & $\begin{array}{c}\text { Density } \\
{\left[\mathrm{kg} / \mathrm{m}^{3}\right]}\end{array}$ \\
\hline 97.05 & 1.50 & 0.15 & 11.19 & 10.09 & 0.74 \\
\hline
\end{tabular}

Source: own study based on Kwaśniewski et al. 2015.

It has been assumed in the research that all analyzed technologies of hydrogen generation will emit $\mathrm{CO}_{2}$ to the atmosphere, at levels which are typical for processes of chemical, thermal, and energy transformations characteristic for a given technology, as well as the analyzed coals and natural gas (Taniewski 2012).

The values of average yearly emissions of carbon dioxide for the primary fuels analyzed are presented in Table 3, together with all key variables describing both technological variants. It can be noted that the yearly emission of $\mathrm{CO}_{2}$ in the case of steam methane reforming (SMR) amounts to some $55 \%$ of the emissions generated in the process of lignite gasification in the Shell reactor.

TABLE 3. Key technical outputs describing analyzed technologies

TABELA 3. Kluczowe techniczne rezultaty analizowanych technologii

\begin{tabular}{|c|c|c|c|}
\hline Parameters & Unit & $\begin{array}{c}\text { Gasification } \\
\text { (Shell) }\end{array}$ & SMR \\
\hline Input fuel (feed) & & Lignite & Natural gas \\
\hline Yearly consumption of input fuel & $\begin{array}{c}\mathrm{Mg} / \mathrm{yr} \\
\mathrm{m}^{3} / \mathrm{yr}\end{array}$ & $1,592,353$ & $472,055,826$ \\
\hline Efficiency of conversion of the raw material to product & $\%$ & 52.2 & 72.5 \\
\hline Net hydrogen production & $\mathrm{Mg} / \mathrm{yr}$ & 73,770 & 103,520 \\
\hline Availability & $\%$ & 90 & 90 \\
\hline Yearly emission of carbon dioxide & $\mathrm{Mg} / \mathrm{yr}$ & $1,688,918$ & 923,535 \\
\hline
\end{tabular}

Source: own study based on Kwaśniewski et al. 2015.

\section{Methodology of evaluation - hydrogen generation cost}

The levelized cost of electricity (LCOE) is presently a standard for the evaluation and comparison of energy engineering technologies, particularly those aimed at the generation of electricity. It may also be successfully used for analyzing any other end product. 
The general definition of that indicator is expressed as a quotient of total costs (capital expenditure and operational ones) to the total amount of generated product. Thus, it is such a price of the end product which, throughout the time of technology functioning (phase of investment and phase of operation), guarantees covering the costs of operation, investment outlays, costs of debt servicing, as well as the required return for investors. As can be easily noticed, that definition includes, in the line of costs, also the required profit for investors - providers of capital, and is often expressed as a percent of revenues meant for that purpose (DOE NETL 2011; Kwaśniewski et al. 2014, 2016).

The used method of calculation of that cost is that which in formula 1 comprises only the cash-based cost of operation (that is, the cost of operation without depreciation), including the costs of fuel purchased and investment outlays.

The tool used for calculating total cost (investment outlays and cost of operation) per unit of hydrogen produced was a spreadsheet utilizing a model based on discounted cash flow analysis (DCF), in which the risk was taken into account in a discount rate.

$$
\mathrm{LCOH}_{2}=\frac{\sum_{t=1}^{n}\left(N I_{t}+K O_{t}+K P_{t}\right)(1+r)^{-1}}{\sum_{t=1}^{n} P H_{2_{t}}(1+r)^{-t}}
$$

where:

$\mathrm{LCOH}_{2}$ - levelized unit cost of hydrogen generation,

$n \quad-$ period of cost averaging (economic lifetime of the project),

$N I_{t} \quad-\quad$ investment outlays (capex) in year $t$,

$\mathrm{KO}_{t} \quad-$ cost of operation (excluding fuel cost) in year $t$,

$K P_{t} \quad-$ cost of fuel in year $t$,

$\mathrm{PH}_{2 t} \quad-$ hydrogen production in year $t$,

$r \quad-$ discount rate,

$t \quad-$ year.

\section{Key macroeconomic assumptions}

The methodology of assessing the economic efficiency of analyzed technologies of hydrogen production, the crucial element of which is the evaluation of $\mathrm{LCOH}_{2}$ focuses of outlays and costs of key technological processes and revenue/income components corresponding to them.

Within the investment outlays, the expenditures connected with the development of technological infrastructure of processes, auxiliary infrastructure, construction works, design documentation, or reconstruction outlays have been taken into account. Investment outlays have 
been calculated at the level of TPC (Total Plant Costs) as well as after taking other overheads/ surcharges and reserves into account (demand for working capital, materials, and chemicals in the start-up phase and reserve amounting to $15 \%$ of TPC) - as Total As Spent Costs (TASC).

In the costs of operation, in turn, the following have been included for each technology discussed: use of materials and chemicals (cost of charge fuel - gas and lignite), chemicals, other raw materials and materials), energy and utilities (electricity, utilities - water, central heating), third party services (repairs, services, and overhauls), taxes and charges (real property taxes and insurance costs, costs of $\mathrm{CO}_{2}$ emission allowances, charges for using the environment), salaries and related costs, depreciation, other costs of operation connected with plant closure and waste management.

The cost of general management (administration and support) amounted to $30 \%$ of the personnel costs, and were included together with other personnel costs, under the item "remunerations". Costs of taxes and charges have been calculated as a surcharge to TPC, in the amount of $0.7 \%$, whereas the costs of insurance amounted to $0.5 \%$ of TPC. Costs of repairs, services, and overhauls have been calculated on an individual basis.

The key macroeconomic assumptions, of importance in the process of pricing the analyzed technologies are presented below:

४ the pricing was updated at the beginning of 2019 ,

$\downarrow$ calculations have been made in nominal prices for detailed forecast comprising the first 10 accounting periods. Starting in year 11, the values of key variables influencing decision-making have been assumed at the level of year 10 values. The projected inflation (CPI) target at the level of $2.5 \%$ (the path projected to the year 2021, according to NBP (National Bank of Poland) projections),

$\downarrow$ investment outlays for all variants have been expressed in a three-year perspective. The entire calculation time horizon comprises 34 periods, the phase of winding up falls on the last year,

TABLE 4. Key economic and technical variables/parameters obtained for analyzed technologies

TABELA 4. Kluczowe ekonomiczne i techniczne zmienne/parametry osiągnięte $\mathrm{w}$ analizowanych technologiach

\begin{tabular}{|l|c|c|c|}
\hline \multicolumn{1}{|c|}{ Parameters } & Unit & $\begin{array}{c}\text { Gasification } \\
\text { (Shell) }\end{array}$ & SMR \\
\hline Total investment cost & PLN million & 4156.1 & 574.7 \\
\hline Unit investment cost & thous. PLN/Mg & 56.3 & 5.5 \\
\hline Yearly average costs of operation & PLN million & 622.7 & 501.9 \\
\hline Yearly costs of fuel & PLN million & 278.0 & 344.2 \\
\hline Share of costs of fuel in yearly costs of operation & $\%$ & 45 & 69 \\
\hline Yearly costs of $\mathrm{CO}_{2}$ emission allowances & PLN million & 162.3 & 88.7 \\
\hline Share of costs of $\mathrm{CO}_{2}$ emission allowances in yearly costs of operation & $\%$ & 26 & 18 \\
\hline
\end{tabular}

Source: own study based on Kwaśniewski et al. 2015. 
the price of electricity purchased to cover own consumption not covered by means of chemical energy in the system has been assumed at PLN 400/MWh,

$\checkmark$ the basic price level for lignite used in the technologies has been determined at PLN 170/Mg,

$\downarrow$ the price of natural gas has been established at the level of PLN $0.71 / \mathrm{m}^{3}$,

$\downarrow$ the starting price of carbon credits $\left(\mathrm{CO}_{2}\right.$ emission allowances) has been calculated on the basis of exchange quotations at PLN $100 / \mathrm{Mg}$,

$\checkmark$ the cost of capital has been established at the level of $6.4 \%$.

\section{Discussion of evaluation results}

Table 5 presents the results of calculations of hydrogen production costs $\left(\mathrm{LCOH}_{2}\right)$ for the analyzed technologies.

TABLE 5. The costs of hydrogen production $\left(\mathrm{LCOH}_{2}\right)$ for analyzed technologies

TABELA 5. Koszt produkcji wodoru $\left(\mathrm{LCOH}_{2}\right)$ w analizowanych technologiach

\begin{tabular}{|c|c|c|}
\hline & Lignite & Natural gas \\
\hline $\mathrm{LCOH}_{2}[\mathrm{PLN} / \mathrm{Mg}]$ & 17302.08 & 7452.19 \\
\hline
\end{tabular}

Source: own study.

In line with the attached table, the cost of production of one $\mathrm{Mg}$ of hydrogen in the technology of steam reforming of natural gas (SMR) accounts for $42 \%$ of the costs of hydrogen production based on lignite. It should be noted, however, that the result is strictly correlated with the underlying price level of the main components making up value, in particular:

$\checkmark$ the price of lignite: PLN 170/Mg,

$\checkmark$ the price of natural gas: PLN $0.71 / \mathrm{m}^{3}$,

$\checkmark$ the price of allowances to emit $\mathrm{CO}_{2}: \mathrm{PLN} 100 / \mathrm{Mg}$.

Those parameters may, as history teaches us, be the subject of dynamic changes. Prices of lignite may be subject to individual negotiations, on the basis of demand and installation location. Prices of natural gas, albeit subject to a substantial reduction in recent years, are not guaranteed and depend largely on foreign suppliers. In the case of allowances for $\mathrm{CO}_{2}$ emissions, the available forecasts indicate expectations that they will increase, however, also in this case the present geopolitical situation and legislation efforts of the EU make this parameter highly volatile, which significantly influences the obtained results.

The above prompts the question concerning the conditions in which, for the presented value components and risks, the production of hydrogen with the use of described/proposed technologies would be profitable. To answer that question, the authors of the study carried out a detailed 
sensitivity analysis for both variants, for variable price levels of lignite/coal, gas, and allowances concerning $\mathrm{CO}_{2}$ emissions.

Tables 6 and 7 contain the results of sensitivity analysis, that is updated costs of hydrogen production as a variability function of the above key parameters for decision-making. The results for the assumed underlying prices are presented in bold.

TABLE 6. Cost of hydrogen production using $\mathrm{LCOH}_{2}$ standard [thousand PLN/ Mg] using the SMR technology for various levels of gas prices and prices of allowances for $\mathrm{CO}_{2}$ emissions

TABELA 6. Koszt produkcji wodoru $\mathrm{LCOH}_{2}$ [PLN/Mg] w technologii SMR dla zmiennych poziomów ceny gazu i pozwoleń na emisję $\mathrm{CO}_{2}$

\begin{tabular}{|c|c|c|c|c|c|c|c|c|c|c|c|c|c|c|c|}
\hline & & \multicolumn{13}{|c|}{ Price of gas $\left[\mathrm{PLN} / \mathrm{m}^{3}\right]$} \\
\hline & & & 0.7 & 0.9 & 1.0 & 1.1 & 1.3 & 1.4 & 1.6 & 1.7 & 1.8 & 2.0 & 2.1 & 2.3 & 2.4 \\
\hline & & & \multicolumn{13}{|c|}{$\mathrm{LCOH}_{2}$} \\
\hline \multirow{15}{*}{ 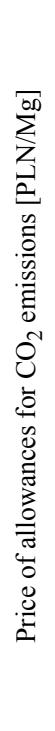 } & 20 & \multirow{15}{*}{ 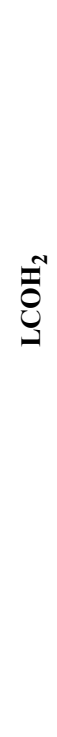 } & 6.3 & 7.2 & 8.2 & 9.1 & 10.0 & 10.9 & 11.9 & 12.8 & 13.7 & 14.7 & 15.6 & 16.5 & 17.5 \\
\hline & 40 & & 6.6 & 7.5 & 8.4 & 9.4 & 10.3 & 11.2 & 12.2 & 13.1 & 14.0 & 14.9 & 15.9 & 16.8 & 17.7 \\
\hline & 60 & & 6.9 & 7.8 & 8.7 & 9.6 & 10.6 & 11.5 & 12.4 & 13.4 & 14.3 & 15.2 & 16.1 & 17.1 & 18.0 \\
\hline & 80 & & 7.1 & 8.1 & 9.0 & 9.9 & 10.8 & 11.8 & 12.7 & 13.6 & 14.6 & 15.5 & 16.4 & 17.4 & 18.3 \\
\hline & 100 & & 7.5 & 8.3 & 9.3 & 10.2 & 11.1 & 12.1 & 13.0 & 13.9 & 14.8 & 15.8 & 16.7 & 17.6 & 18.6 \\
\hline & 120 & & 7.7 & 8.6 & 9.5 & 10.5 & 11.4 & 12.3 & 13.3 & 14.2 & 15.1 & 16.0 & 17.0 & 17.9 & 18.8 \\
\hline & 140 & & 8.0 & 8.9 & 9.8 & 10.7 & 11.7 & 12.6 & 13.5 & 14.5 & 15.4 & 16.3 & 17.2 & 18.2 & 19.1 \\
\hline & 160 & & 8.2 & 9.2 & 10.1 & 11.0 & 11.9 & 12.9 & 13.8 & 14.7 & 15.7 & 16.6 & 17.5 & 18.5 & 19.4 \\
\hline & 180 & & 8.5 & 9.4 & 10.4 & 11.3 & 12.2 & 13.2 & 14.1 & 15.0 & 15.9 & 16.9 & 17.8 & 18.7 & 19.7 \\
\hline & 200 & & 8.8 & 9.7 & 10.6 & 11.6 & 12.5 & 13.4 & 14.4 & 15.3 & 16.2 & 17.1 & 18.1 & 19.0 & 19.9 \\
\hline & 220 & & 9.1 & 10.0 & 10.9 & 11.8 & 12.8 & 13.7 & 14.6 & 15.6 & 16.5 & 17.4 & 18.3 & 19.3 & 20.2 \\
\hline & 240 & & 9.3 & 10.3 & 11.2 & 12.1 & 13.1 & 14.0 & 14.9 & 15.8 & 16.8 & 17.7 & 18.6 & 19.6 & 20.5 \\
\hline & 260 & & 9.6 & 10.5 & 11.5 & 12.4 & 13.3 & 14.3 & 15.2 & 16.1 & 17.0 & 18.0 & 18.9 & 19.8 & 20.8 \\
\hline & 280 & & 9.9 & 10.8 & 11.7 & 12.7 & 13.6 & 14.5 & 15.5 & 16.4 & 17.3 & 18.2 & 19.2 & 20.1 & 21.0 \\
\hline & 300 & & 10.2 & 11.1 & 12.0 & 12.9 & 13.9 & 14.8 & 15.7 & 16.7 & 17.6 & 18.5 & 19.5 & 20.4 & 21.3 \\
\hline
\end{tabular}

Source: own study.

As can easily be noticed, the most advantageous results are those of hydrogen production technology applying natural gas steam reforming (SMR). The updated costs of $\mathrm{H}_{2}$ vary in the range between PLN 6.3 and 21.3 thousand/Mg of $\mathrm{H}_{2}$ for the technology based on natural gas, and between PLN 10.3 and 32.8 thousand/Mg of hydrogen in the case of lignite gasification.

It is worth noting that only a double increase of gas price, with a simultaneous reduction by $80 \%$ of the prices of lignite and allowances for $\mathrm{CO}_{2}$ emissions provides advantage to the technology of lignite gasification. Additionally, the influence of changes in the prices of allowances for $\mathrm{CO}_{2}$ emissions is far less significant than in the case of gasification technology. In the analyzed 
TABLE 7. Cost of hydrogen production using $\mathrm{LCOH}_{2}$ standard [thousand PLN/ Mg] using the gasification technology for various levels of lignite prices and prices of allowances for $\mathrm{CO}_{2}$ emissions

TABELA 7. Koszt produkcji wodoru $\mathrm{LCOH}_{2}[\mathrm{PLN} / \mathrm{Mg}]$ w technologii SMR dla zmiennych poziomów ceny węgla brunatnego i pozwoleń na emisję $\mathrm{CO}_{2}$

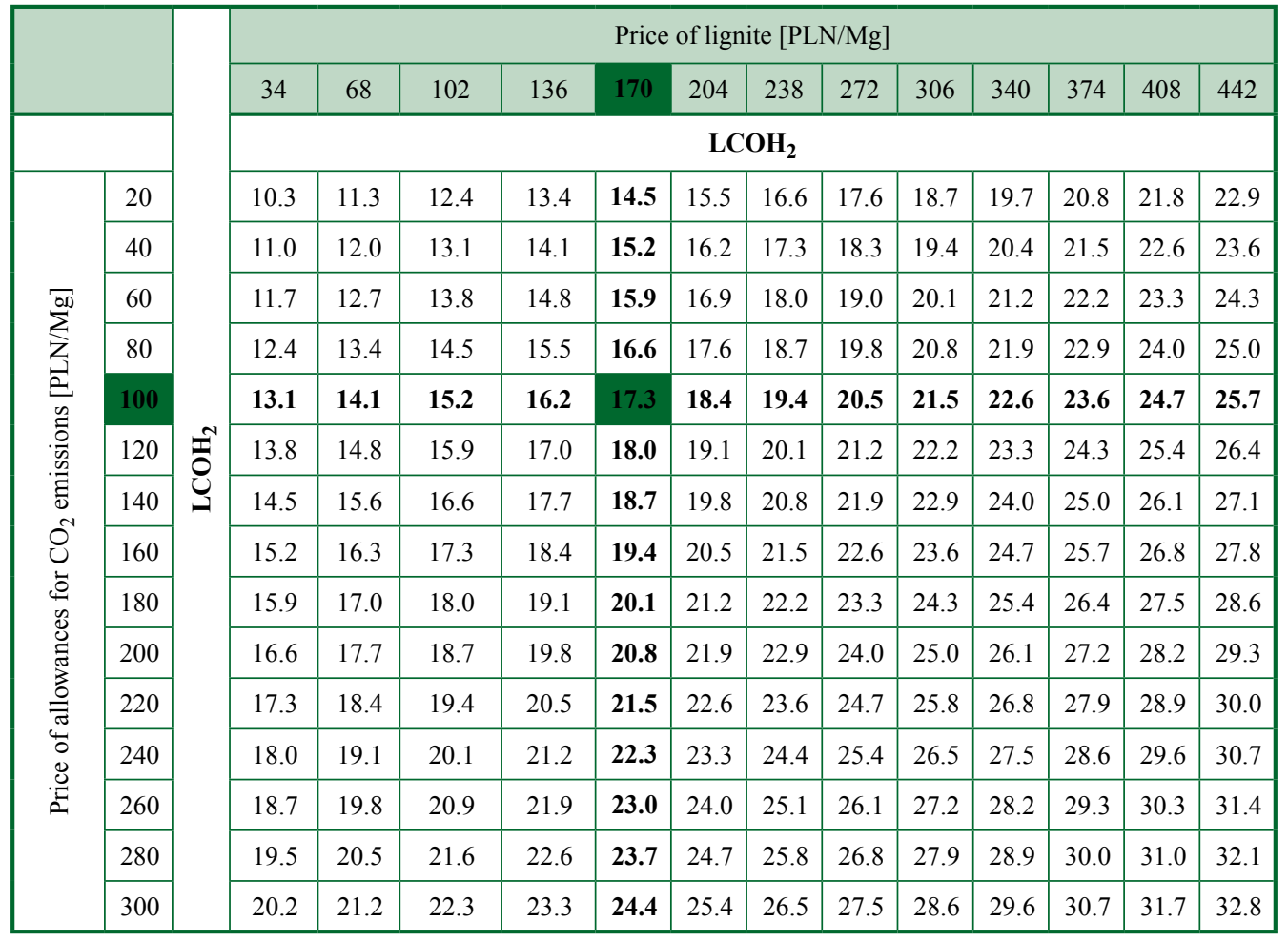

Source: own study.

range of prices of allowances for emissions, the $\mathrm{LCOH}_{2}$ increases by $96 \%$ for lignite (baseline: PLN $170 / \mathrm{Mg}$ ) and by $61 \%$ for natural gas (baseline: PLN $0.71 / \mathrm{m}^{3}$ ).

In order to analyze the results obtained in more detail, Tables 6 and 7 have been combined in order to obtain the boundary price of lignite, for which the gasification technology gets advantage for the determined prices of gas and allowances for $\mathrm{CO}_{2}$ emissions. The results of the analysis are presented in Table 8.

One can notice that only for gas prices starting from the level of PLN $1.4 / \mathrm{m}^{3}$ production of hydrogen is profitable with the application of lignite gasification, under the condition that lignite prices drop to the level of PLN 34/Mg of coal, and prices of allowances for $\mathrm{CO}_{2}$ emission go down to the level of PLN 20/Mg. Presently, such a situation appears to be completely unrealistic. For the assumed lignite prices (PLN 170/Mg) and prices of allowances for $\mathrm{CO}_{2}$ emission (PLN 100/Mg) the boundary price of gas that would make SMR technology unprofitable is PLN $2.3 / \mathrm{m}^{3}$, which also seems hardly realistic in the present market situation. 
TABLE 8 . Boundary prices of lignite [PLN/ Mg] for which the costs of hydrogen production, applying the $\mathrm{LCOH}_{2}$ standard, by means of gasification becomes economically profitable

TABELA 8. Graniczne poziomy cen węgla brunatnego [PLN/Mg], dla których koszt produkcji wodoru $\mathrm{LCOH}_{2}$ w technologii zgazowania węgla jest niższy

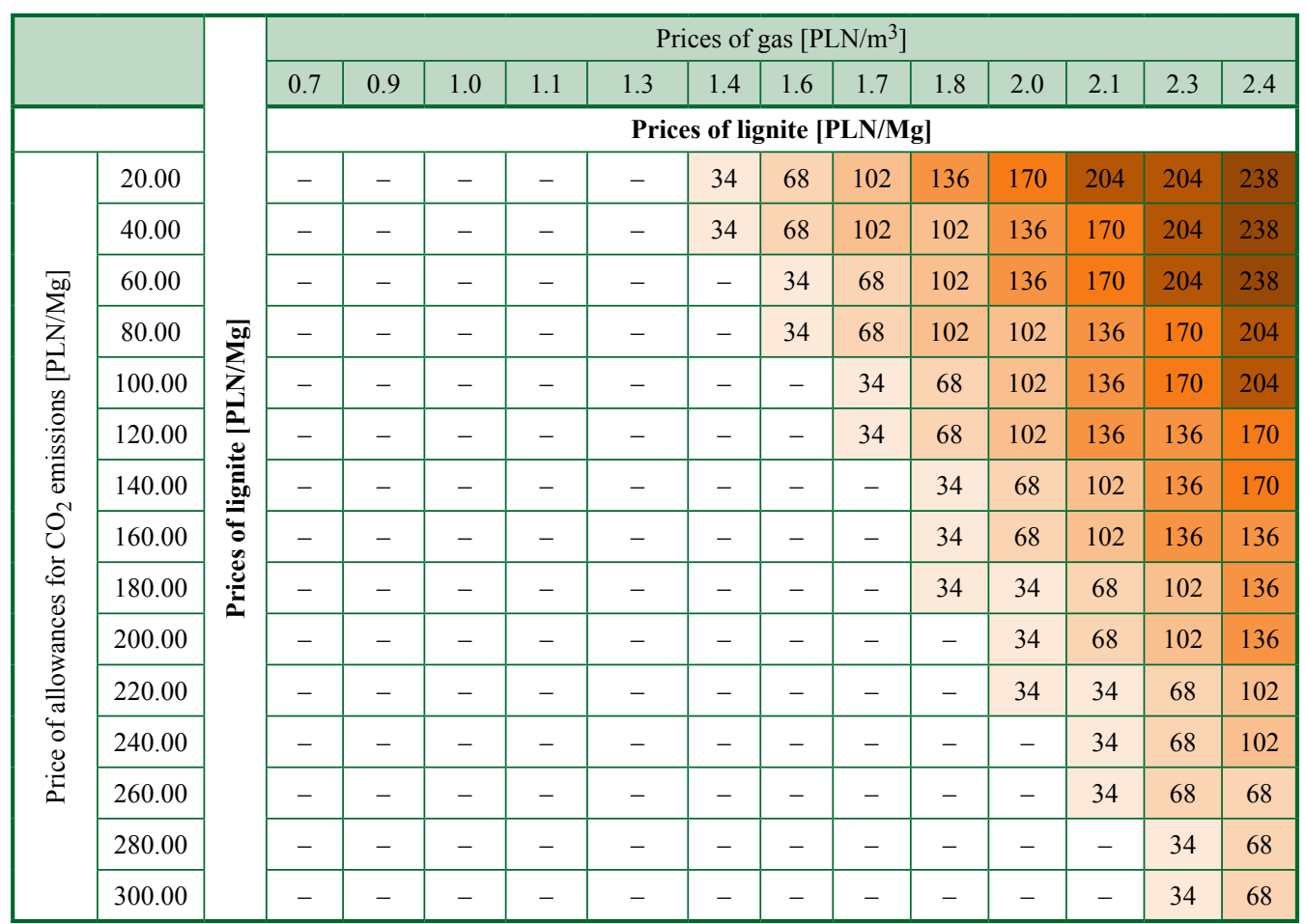

Source: own study.

\section{Conclusion}

The paper presents the costs of hydrogen production in the process of lignite gasification in the Shell reactor, and - alternatively - in the technology of steam reforming of natural gas (SMR).

As a criterion for making decisions, the authors assumed the unit cost of production expressed as $\mathrm{LCOH}_{2}$. That standard/indicator represents the price of hydrogen produced, which over the entire lifetime of the technology guarantees covering the cost of operation and investment outlays, for the return on invested capital, assumed by the investors.

For the assumed initial assumptions, the technology of steam reforming of natural gas (SMR) turns out to provide much better results, with the cost of producing one Mg of hydrogen amounting to PLN 7.5 thousand. For the same conditions, the cost of producing one Mg of hydrogen 
by means of lignite gasification has been assessed at PLN 17.3 thousand. Subsequently, the influence of changes in prices upon the selection of optimum technology of hydrogen production has been analyzed, specifically :

$\checkmark$ gas: $0.7-2.4\left[\mathrm{PLN} / \mathrm{m}^{3}\right]$,

$\downarrow$ lignite/coal: $34-442[\mathrm{PLN} / \mathrm{Mg}]$,

$\checkmark$ allowances for $\mathrm{CO}_{2}$ emission: $20-300$ [PLN/Mg].

From the scenarios described by means of prices of lignite and of natural gas, the scenarios describing an increase of gas prices have been distinguished, which are less probable in the current situation, also - on the other hand - the scenarios of low and high prices of lignite.

The question remains open whether the market conditions, in which it is possible to replace the economically efficient production of hydrogen applying SMR technology, by means of alternative solutions. The analysis indicated explicitly the range of gas prices (up to PLN $1.3 / \mathrm{m}^{3}$ ), in which such substitution is not profitable, taking the economic situation into account. Under the present market and geopolitical situation, the application of lignite gasification technology for hydrogen production proves unprofitable, regardless of the prices of allowances for $\mathrm{CO}_{2}$ emissions. Only a drastic increase of gas prices and the limitation of its availability may change that opinion, as well as a substantial drop of prices of lignite as fuel. In such a situation, one should consider the possibility of using refuse-derived fuel (RDF) in the gasification processes (Prasertcharoensuket al. 2019). Such a solution could significantly reduce or completely replace lignite as fuel, also giving positive environmental results.

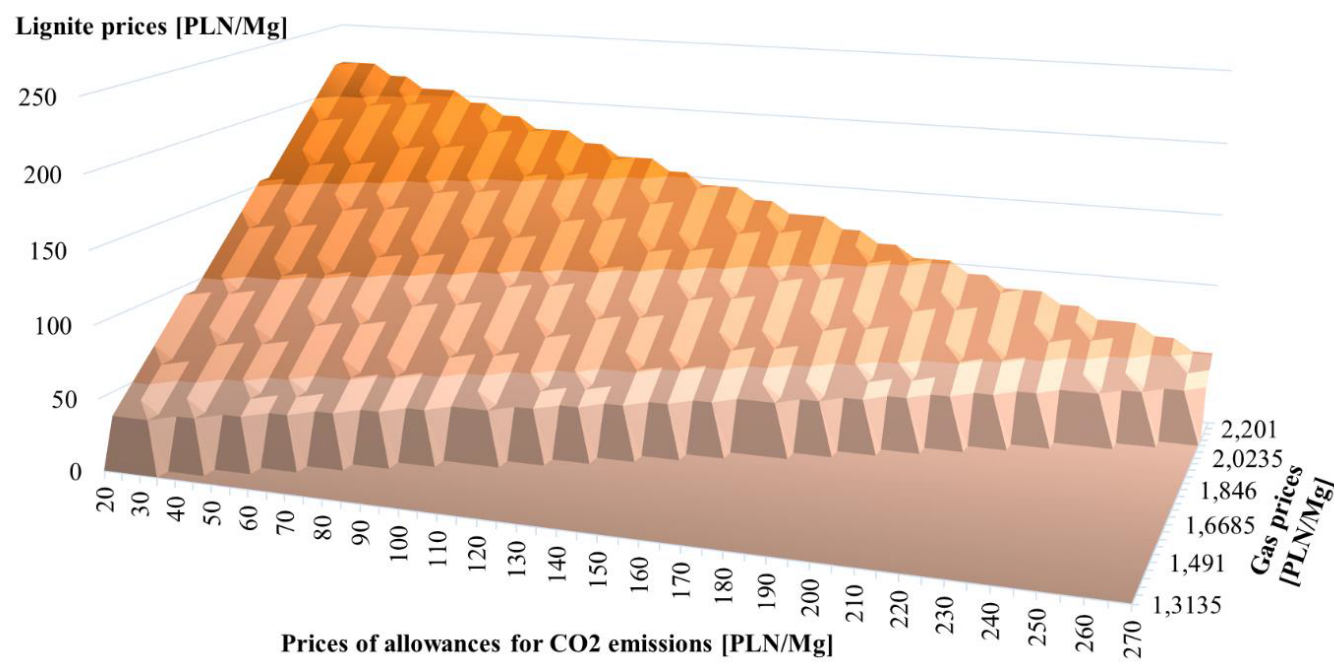

Fig. 3. Economically efficient production of hydrogen applying the analyzed technologies in relation to prices of gas $\left[\mathrm{PLN} / \mathrm{m}^{3}\right]$, lignite $[\mathrm{PLN} / \mathrm{Mg}]$, and allowances for $\mathrm{CO}_{2}$ emission $[\mathrm{PLN} / \mathrm{Mg}]$ Source: own study

Rys. 3. Efektywna ekonomicznie produkcja wodoru w analizowanych technologiach w relacji do cen gazu ziemnego $\left[\mathrm{PLN} / \mathrm{m}^{3}\right]$, węgla brunatnego [PLN/Mg] oraz pozwoleń na emisję $\mathrm{CO}_{2}[\mathrm{PLN} / \mathrm{Mg}]$ 
One should remember that the choice of proper strategy for hydrogen production is connected with determining the field of applications, as well as defining other assumptions, for which the investments based on lignite gasification, may guarantee satisfactory efficiency. The ultimate decision for investment, concerning the possibility and technology of hydrogen generation should also take the non-economic factors, such as: stability of supplies of imported gas, possibilities of having access to cheaper lignite in a longer perspective, or the necessity of processing municipal as well as industrial waste into account.

The publication has been financed using a subsidy for maintenance and development of research potential.

\section{References}

British Petroleum BP: Energy Outlook. [Online] https://www.bp.com/content/dam/bp/business-sites/en/ global/corporate/pdfs/energy-economics/energy-outlook/bp-energy-outlook-2019.pdf [Accessed: 2019-05-27].

CHMIELNIAK et al. 2013 - CHMIELNIAK, T., ŚCIĄŻKo, M. i SOBOLEWSKI, A. 2013. Fluidized bed gasification of coal in $\mathrm{CO}_{2}$ atmosphere (Fluidalne zgazowanie węgla w atmosferze $\mathrm{CO}_{2}$ ). Karbo 1, pp. 6-15 (in Polish).

CHMiELNiAK, T. 2014. Simulation analyzes of hydrogen production technology in the aspect of $\mathrm{CO}_{2}$ emissions - coal mining, transport and processing (Badania symulacyjne technologii wytwarzania wodoru w aspekcie emisji $\mathrm{CO}_{2}-$ wydobycie, transport i przetwórstwo wegla). Monografia, Gliwice: Wydawnictwo Politechniki Śląskiej (in Polish).

DOE NETL: Quality guidelines for Energy System Studies: Cost Estimation Methodology for NETL Assessments for Power Plant Performance: DOE/NETL-2011/1455, April 2011.

KWAŚNIEWSKI et al. 2014 - KWAŚNIEWSKI, K., KoPACZ, M., GrZESIAK, P. and KAPŁAN, R. 2014. Assessment of economic effectiveness of selected coal gasification technologies (Ocena efektywności ekonomicznej wybranych technologii zgazowania wegla). Karbo 4, pp. 202-213 (in Polish).

KWAŚNIEWSKI et al. 2015 - KWAŚNIEWSKI, K. eds., KOPACZ, M. eds., GRZESIAK, P., KAPŁAN, R. and SOBCZYK, E.J. 2015. Coal gasification - conditions, effectiveness and perspectives for development, AGH, Kraków.

KWAŚNIEWSKI et al. 2016 - KWAŚNIEWSKI, K., KopACZ, M., KAPŁAN, R., GRZESIAK, P. and SOBCZYK, J. 2016. Economic assessments of hydrogen production by coal gasification (Ocena ekonomiczna wytwarzania wodoru przez zgazowanie wegla). Przemyst Chemiczny 95, No. 2, pp. 241-249. Bibliogr. p. 249, Kraków.

LuQue, R. and Speight, J. 2015. Gasification for Syntetic Fuel Production. Woodland Publishing Series In Energy 69, Elsevier Ltd. (p. 11).

MCHugh et al. 2005 - MCHugh, K., Eisele, S. and NeSTELl, J. 2005. Hydrogen production methods. MPR Associates, Inc. MPR-WP-0001.

MOLENDA, J. 2008. Hydrogen energetics - technologies and perspectives (Energetyka wodorowa - technologie i perspektywy). Wszechświat vol. 108, No. 04-06 (in Polish).

Regulation (EU) 2019/943 of the European Parliament and of the Council of 5 June 2019 on the internal market for electricity. Bruksela 2019 [Online] https://eur-lex.europa.eu/legal-content/PL/TXT/HTML/?uri=CELEX:32019R0943\&from=EN [Accessed: 2019-06-21]. 
Prasertcharoensuk et al. 2019 - Prasertcharoensuk, P., Bull, S.J. and Phan, A.N. 2019. Gasification of waste biomass for hydrogen production: Effects of pyrolysis parameters. Renewable Energy Vol. 143.

SurygaŁA, J. 2008. Hydrogen as a fuel (Wodór jako paliwo). Warszawa: Scientific and Technical Publishing House (in Polish).

TANIEWSKI, M. 2012. Syngas and carbon dioxide chemistry. Review of today's opportunities (Chemia gazu syntezowego i ditlenku węgla. Zarys wspótczesnych możliwości). Przemyst Chemiczny 91/4 (in Polish).

YANG, J. 2019. Hydrogen as an Energy Carrier: Can China accelerate the path down the learning curve? [Online] https://ihsmarkit.com/research-analysis/hydrogen-as-an-energy-carrier-can-china-accelerate -the-path.html [Accessed: 2019-10-23].

Michał KoPACZ, Radosław KAPŁAn, Krzysztof KWAŚNIEWSKI

\section{Ocena efektywności ekonomicznej wytwarzania wodoru na drodze zgazowania węgla brunatnego}

\section{Streszczenie}

Wodór jako surowiec ma głównie zastosowanie na rynku Polskim w przemyśle chemicznym, jednak coraz częściej są szeroko analizowane i komentowane jego perspektywiczne zastosowania do produkcji energii w układach ogniw paliwowych czy jako paliwa samochodowego.

W chwili obecnej na świecie wodór wytwarzany jest głównie z gazu ziemnego przy wykorzystaniu technologii reformingu parowego lub na drodze elektrolizy wody. Wyjątkiem są kraje dysponujące dużymi zasobami węgla, gdzie jego produkcja jest coraz częściej oparta na procesach zgazowania. Takim przykładem są Chiny, gdzie około $68 \%$ wodoru wytwarzane jest $\mathrm{z}$ węgla.

Artykuł porusza tematykę oceny efektywności ekonomicznej technologii produkcji wodoru na drodze zgazowania węgla brunatnego odnosząc ją do technologii reformingu parowego gazu ziemnego (SMR). Aktualnie, w warunkach polskich technologia ta wydaje się być najbardziej prawdopodobną alternatywą substytucji gazu ziemnego.

Na potrzeby oceny efektywności ekonomicznej zbudowano model, w którym przeprowadzono analizę wrażliwości, w szczególności zaprezentowano przykładowy proces technologiczny energo-chemicznego przetwarzania węgla brunatnego, bazujący na procesie zgazowania na podstawie układu dyspersyjnego, omówiono charakterystykę paliwa oraz kwestię emisji ditlenku węgla. Następnie szczegółowo opisano przyjętą metodykę oceny ekonomicznej oraz jej kluczowe założenia. Kolejno, bazując na metodzie zdyskontowanych przepływów pieniężnych, wyznaczono jednostkowy koszt wytworzenia wodoru, po czym dokonano szczegółowej analizy wrażliwości, uwzględniając główne czynniki ryzyka, związane z relacją cen węgla i gazu ziemnego oraz ceną pozwoleń na emisje $\mathrm{CO}_{2}$.

SŁowA KLUCZOWE: produkcja wodoru, ocena ekonomiczna, SMR, pozwolenia na emisję $\mathrm{CO}_{2}$, zgazowanie węgla brunatnego 
